\title{
Globalization and the culture/creative industries: An assessment of Nigeria's position in the global space
}

\author{
Chivuzo A.J. Offiah \\ School of Media and Communication (Pan-Atlantic University) Lagos Nigeria
}

\begin{abstract}
Globalization has shaped every facet of human life, and its inevitability has also impacted the culture and creative industries. Driven largely by economic benefits and advances in cross-border communication technologies, globalization of cultural goods and services has been hailed as a welcome development. Many societies are taking advantage of this as an opportunity to export their culture, increase their global soft power, and establish their presence and relevance in the global space. In this regard, Nigeria competes with many other countries. Her cultural output as a nation has been recognized and acknowledged globally, placing her on a pedestal far above her African contemporaries. This success (if one can describe it as such) has been due to the contribution of various segments of the local culture and creative industries, notably the film, music and fashion industries. The concern, however, is whether Nigeria can continue to maintain its place in the global space and sustainably ensure its future relevance. This paper addresses this concern by appraising Nigeria's current position in the global culture and creative industries, identifying challenges threatening this position, and recommending measures for further consolidation of the country's position in the global space.
\end{abstract}

Keywords - creative and culture industries, fashion, globalization, music

\section{INTRODUCTION}

In July 2016, the government of Anambra State (a relatively small-sized state located in the eastern part of Nigeria) announced its first official export of agricultural produce to Europe (Vanguard, 2016). The news created a lot of excitement primarily for two reasons: firstly, the exported vegetables were valued at $\$ 5$ million; and secondly, Anambra became the first Nigerian state to officially export vegetables to Europe. This event is the typical dividend of globalization where trade and price liberalization have continued to facilitate the integration of different economies in the world. In many ways, and for several decades, Nigeria's trade relations with other countries have improved. The country's cocoa export from the 1960s and crude oil production and export from the 1970s have all contributed to increasing Nigeria's relevance in the global economy. As the country matures politically and economically, her developmental capabilities continue to support production systems and output in other sectors of the economy with significant potentials. Today, the local culture and creative industries which used to be considered largely informal and second place are developing at a rapid rate and with increasing quality and sophistication. First intended for local consumption, these cultural outputs have found their way into other African regions, and increasingly being consumed in many countries across the world. There is no doubt that the activities of the local culture and creative industries have also put Nigeria in the global scene. Nigerian fashion and music, for instance, are popular in many countries within the Global North. Nigerian fashion culture has inspired many design creations by iconic designers showcased in celebrated fashion shows around the world. Wakaa the Musical is a one hundred percent Nigerian theatrical show that has received widespread acclaim in the UK. Even though not yet completely integrated into the profit-making network of the global culture and creative industries, Nollywood is globally recognized as one of Nigeria's prominent cultural outputs. In terms of global relevance, the local film industry is spoken of in the same vein as Hollywood and Bollywood. In consideration of all these, the objective of this paper therefore is to assess Nigeria's position in the global culture and creative industries.

Ofcourse, the Nigerian culture and creative industries are much broader than the local film, music and fashion industries. Therefore in assessing Nigeria's position in the global culture space, it can become very unwieldly if this task is not given a specific direction. It should be noted that the term "position", for purposes of this paper, is to be understood in the sense of "a particular way in which something is placed or arranged"(Merriam-Webster Dictionary, 2009). In line with this understanding, this paper focuses on two segments of the Nigerian culture and creative industries (the fashion and music industries), critically and rigorously evaluating their current situations vis-à-vis global realities. As part of appraising the position of these component parts of the Nigerian culture and creative industries, this paper also identifies and analyzes their strengths as well as the challenges facing them. Subsequently, recommendations are put forward on improvements that can be made in these industries to further reinforce Nigeria's position in the global space. 


\section{THE CONCEPT OF GLOBALIZATION}

Globalization, once an exciting buzzword that represented a phenomenon new to many, has now become common, the occurrence of which people witness consciously and unconsciously in their everyday lives. As observed by Larsson (2001) cited in Ibagere (2015), "globalization is the process of world shrinkage, of distances getting shorter, things moving closer. It pertains to the increasing ease with which somebody on one side of the world can interact to mutual benefit with somebody on the other side of the world". Orunmoluyi (2002) cited in Abdulraheem (2010) views globalization as "a process of creating a global market in which increasingly all nations are forced to participate". Both on the individual and collective (countries, societies) level, globalization has occurred and will continue to occur on different dimensions. International trade treaties, for instance, have made it possible for unprecedented levels of economic and political globalization to become common. Today, goods and services originating from a given geographic location can be consumed in any part of the world. National elections and political appointments are influenced by commercial and state-sponsored interest groups within the international community. News of events in any part of the world get circulated around the world in a matter of seconds. In fact events of global interest happening in any given location can be followed real-time by anyone in any part of the world. All these increasingly suggest that "peoples of the world are incorporated into a single world society" (King, 1990 cited in Ibagere, 2015). Perhaps, nowhere is this phenomenon felt more than in the globalization of culture. Cultural globalization has been defined in various ways. Paul (2006) views it as "the transmission of ideas and values around the world in such a way as to extend and intensify social relations". David (2002) interprets cultural globalization to mean "the process of harmonizing different cultures and beliefs". And Castells (1997) cited in Abdulraheem (2010) states "that globalization is the process that erodes differences in culture and produces a seamless global system of culture and economic values". It must be noted that this process continues to be facilitated by traditional and new media, and very much so in this era of advanced digital and communication technologies.

The import of these definitions is a steady standardization and increasing acceptance of cultural practices and expressions of various societies. These practices are also embodied in the systems of production and cultural outputs of the local industries within these societies which get to be consumed globally. This acceptability and global consumption are gradually leading to a breakdown of cultural boundaries, and a "systematic integration of autonomous economies into a global system of production and distribution" (Abdulraheem, 2010). It is within this understanding of globalization that this paper situates the culture and creative industries, and carries out an assessment of Nigeria's position in the global space.

\section{THE CULTURE AND CREATIVE INDUSTRIES}

One of the early attempts to define the creative industries was made by the UK Department of Culture, Media and Sport (DCMS). In a document published in 1998, the DCMS described the creative industries as "those activities which have their origin in individual creativity, skill and talent, and which have the potential for wealth and job creation through the generation and exploitation of intellectual property" (Flew, 2002). The work of the DCMS was so revealing to the UK government at the time, that it established the UK Creative Industries Task Force and charged it with developing this sector in the UK, similar to what was already happening in Australia, Goteburg, Berlin, Milan and Barcelona (Flew, 2002). One of the first activities performed by the task force was to identify the economic sectors within the UK that fit the DCMS definition, and these were: music, software, publishing, performing arts, interactive leisure software, television and radio, design, film, crafts, designer fashion, advertising, architecture, arts and antique markets (Flew, 2002).The DCMS definition of creative industries, which has been interrogated and expanded by researchers in the field, is foundational because it highlights the key attributes or criteria that must be considered in any discussion of the creative industries. These include creativity of the individuals working in the creative industries, methods of production of the creative goods and services, the symbolic meaning of these goods and services, their use value, and the intellectual property that enables producers of creative goods and services to derive economic benefits from their works (Galloway \& Dunlop, 2007). This paper adopts the DCMS definition of creative industries.

It is important to observe that in academic literature, the term "creative industries" has been used interchangeably with the term "culture industries". While some researchers (Cunningham, 2001; Galloway \& Dunlop, 2007) have strongly expressed their disagreement with this apparent conflation of terms, this paper accepts the interchangeability of both terms. Therefore, where the expression or term "culture industries" is encountered, it is to be understood in line with the DCMS definition of the term "creative industries". This also extends to the combination of both terms ("culture and creative industries" or "CCI"). 


\section{The impact of the culture and creative industries on global economy}

The culture and creative industries (CCI) are in a state of continuous evolution and over the past few decades, several sectors within the CCI have collectively witnessed significant developments. Today their impact on the global economy is substantial. In 2013 alone, the CCI worldwide generated revenues in excess of $\$ 2.3$ trillion, much higher than the GDP of India and the revenue generated by all the telecom operators across the globe put together (EY Report, 2015). Fashion only is a \$1.2 trillion global industry (McKinsey, 2015). In the UK alone, the fashion industry contributed $£ 21$ billion to the British economy in 2009, and has since grown by $22 \%$ to account for $3.7 \%$ of the UK GDP (British Fashion Council, 2016). In 2014 only, the US spent more than $\$ 250$ billion on fashion (Leadferret, 2015), and employed 1.9 million people, including more than 17,000 recognized designers (US Congress, 2015). Today, New York is considered one of the world's leading fashion capital, with a fashion segment that is worth over $\$ 98$ billion. As fashion is increasingly being recognized as a significant source of soft power, many cities around the world are pushing known boundaries to establish themselves within this new world order.

As at December 2014, the culture and creative industries were responsible for 30 million jobs worldwide, representing the employment of $1 \%$ of the world's active population, with the top three CCI employers being visual arts, publishing and music at 6.7 million, 3.7 million and 4 million employees respectively (EY Report, 2015). Whilst employment opportunities within the culture and creative industries are available to everyone, they appear to be a special attraction to the young, perhaps because of the inclusive and entrepreneurial nature of the CCI. In Europe, the CCI employs more under-thirties than any other sector, and as reported by the UK government in 2014, has also provided immense opportunities for women. According to Ernst \& Young (2015), 50\% of those employed in the UK music industry in 2014 were women. It is quite instructive to note that the revenue/sales and employment figures reported thus far do not capture the informal sector. There is a thriving informal economy, especially in Africa where reports have estimated 2013 revenue and employment to be $\$ 33$ billion and 1.2 million respectively, though recent reports have suggested higher figures. What is key however, is that the informal economy within the culture and creative industries offers opportunities at a large and growing scale, part of which have been directed to urban development initiatives (like the Guggenheim Museum and other cultural initiatives) that have contributed to improving the identity and attractiveness of urban cities.

Unlike some other industries, the activities of the culture and creative industries are quite vibrant in all the regions of the world, with each region contributing a sizeable and culturally rich output to the global creative economy. In this regard, Asia is in the lead primarily as a consequence of its large population, skilled labour and other attractions that have made it home to some of the largest players in the industry. Europe and North America follow closely in the second and third positions, as can be witnessed, for example, in the influence Paris, London, New York and Milan have on the global fashion scene (which is a key segment of the culture and creative industries). Ranking fourth and fifth respectively are Latin America and Africa, who are currently experiencing rapid and colossal developments, with a momentum that is shaping the entire culture and creative industries, as well as the global economy. As has been highlighted severally in both academic literature and practice, the African and Latin American regions represent the next frontier for iconic developments expected to mould the creative economy in the next century (Godart, 2015).

Perhaps nowhere has the impact of the culture and creative industries been felt more than in the digital space. The CCI accounted for $\$ 200$ billion in global digital sales, with creative content (like software, games, novels) driving the sales of digital devices to the tune of $\$ 530$ billion, all in the single year of 2013 (EY Report, 2015). As noted by the same report, digital goods produced by the culture and creative industries are by far the largest source of revenue for the digital economy, with $\$ 66$ billion attributed to direct business-to-consumer sales, and \$22 billion from online advertising, all in 2013 alone. CCI activities have definitely driven the online economy, and this trend is expected to continue well into the foreseeable future.

Africa, without doubt, is one of the greatest beneficiaries of the developments within the culture and creative industries. The CCI have been an outlet for the expression of Africa's multi-cultural richness, as well as an opportunity for the continent to play on the global stage. Today, African traditional art and fashion are being celebrated across the world, and the continent's music and literary works have found appeal amongst American, European and Asian consumers, with African music festivals (like the FESPAM and MASA in Brazzaville and Abidjan respectively) attracting large audiences. Driven both by market demand and the economic needs of cultural producers, African content is increasingly being accessed within the continent, and exported to the international community. Even amongst Africans, there is an increasing appetite for local cultural goods and services, and the consumption of such content has been fueled by improvements in the continent's telecommunication infrastructure, as well as penetration of digital devices that have facilitated better access to the Internet. As Africa's largest economy, the contribution of Nigeria to the global cultural and creative economy cannot be overlooked. The country's thriving film production industry (Nollywood) is widely acknowledged in the international community. Directly employing 300,000 people, Nollywood is Nigeria's 
second largest employer of labour (behind agriculture), and generates an annual revenue of $\$ 800$ million (WIPO Report, 2014). This revenue figure accounts for $2 \%$ of Nigeria's rebased GDP. Globally, Nollywood is the second largest movie industry in the world, with a production turnover of 40 films per week (WIPO Report, 2014). Nollywood movies are very popular in Nigeria, but are rapidly gaining popularity across Africa and the world. As a matter of fact, the industry's very informal structure and low production budgets ensure that there is a continuous supply to meet the escalating demand. Digital companies like IrokoTV are also ensuring that access to Nollywood films is always available.

But Nigeria is also known for its dynamic music industry. According to Ernst \& Young (2015), Nigeria has the most mature music industry in Africa, with 550 albums produced every year, and sales expected to reach $\$ 1$ billion by the end of 2016. Already, live performances contribute an excess of $\$ 100$ million yearly, and developments in the digital technology space have attracted international companies like Apple, and created sufficient room for local players like Spinlet and Iroking.

Irrespective of the perspective (local, regional or global) one chooses to look at it, the culture and creative industries have over the years evolved significantly, and today play a pivotal role in the global economy. Music for instance is dictating growth rates and pace of development in other industries (mobile phone manufacturing, internet broadband subscription and consumption, etc.), and other culture and creative outputs are helping to define the attractiveness of urban centres. Better still, this trend is expected to continue, with the prospects of the music industry being brighter than ever. Music and the culture and creative industries are a force to reckon with and can no longer be ignored.

\section{ASSESSING NIGERIA'S POSITION IN THE GLOBAL CULTURE AND CREATIVE INDUSTRIES}

\section{Nigeria's fashion industry}

The local fashion industry is increasing being acknowledged and recognized globally (Lloyd, 2014). Today, creations by Nigerian designers have been worn by Michelle Obama, celebrities and other pop culture icons in Europe and the United States of America. This recognition is driven by the events and activities of stakeholders, many of whom have made the city of Lagos their home and base of operation. Fashion activities are prevalent in many parts of Nigeria, but just like was the case with Paris and France (Godart, 2012), local and international media have promoted the industry to the point where Lagos is now almost synonymous with everything related to fashion in Nigeria. This is not out of place as globally, the fashion industry is spoken of in terms of cities whose unique identities shape the production systems and output of the industry.

The story of the Lagos fashion industry (understood broadly to include fashion activities in other parts of Nigeria) is largely a representation of the story of African fashion. African fashion has evolved significantly over the last several years. Before now, donning African prints was seen as a manifestation of poverty or a rural way of life. But perceptions have changed. There is a widespread acceptance of African fashion culture both within and outside the continent, and African prints are now symbolic of a high social status. As observed by a notable Malawian designer, "Africans are now becoming more and more identified with their local brands. We have celebrities and government figures wearing local brands. There is a sense of Africaness in their way of dressing" (Krumova, 2014). Even amongst top European fashion brands, there is a growing trend that has seen more and more African concepts being introduced into Western designs. Examples of such are seen in the recent collections of Anna Sui, Tory Burch, Stella McCartney and other celebrity designers. African designers are also leading from the forefront, with celebrated collections coming from top designers in Dar-es-Salaam, Dakar, Nairobi and ofcourse Lagos. The Lagos fashion industry has produced a handful of talented designers like Deola Sagoe, Zizi Cardow, Folake Folarin-Coker (of Tiffany Amber), Duro Olowu, Ohimai Atafo, Ade Bakare and Lisa Folawiyo. These designers are using their huge economic and social capital to put Nigerian fashion on the global map, by supporting local fashion events and participating in the prestigious and highly acclaimed New York, Paris and Milan Fashion Week events. The Lagos fashion industry continues to produce skilled designers who utilize local events, print, online and social media to showcase their creations to the world. The growing online population and ease of setting up ecommerce shops mean more opportunities for these designer to also earn revenue by retailing their creations to a global audience. However, as noted by Krumova (2014), the local fashion industry lacks a coordinated way of developing the huge amount of potentials it has. Just like in many other African cities, Lagos has numerous vocational training academies where fashion is taught, but no notable school of fashion comparable to the Pratt Institute, Fashion Institute of Technology, or Antwerp's Royal Academy of Fine Arts. This means that any upcoming designer that wants to make an impact has to find a way of travelling abroad to be properly educated. Of course the fashion business is much more than knowing how to handle fabric. There are numerous activities within the value chain that require mastering in order to be successful on a global scale. The shortage of competent individuals in this regard is proving a serious challenge 
to the globalization of the local fashion industry, and has to be addressed to ensure a continuous and sustainable pipeline of talented Nigerian designers and fashion entrepreneurs with the capacity to make global impact.

This is one important area where the Lagos fashion industry can learn from more developed fashion centres around the world (e.g. London, Paris, etc.). Institutions where academics and fashion industry stakeholders collaborate to generate and transmit knowledge is a critical element of the structure of the fashion industry both globally and locally. There is the example of the New York fashion industry where key stakeholders in order to meet consumer demands for more unique creations had to focus on developing innovative designs and manufacturing processes (Godart, 2012). This necessarily led to the establishment of respected design and fashion schools like the Parson School of Design. There is also the example of the Royal Academy of Fine Arts in Antwerp. Both schools are attracting young talented fashion enthusiasts who will contribute to the development of those local fashion industries. The need for a world-class fashion institute cannot be over-emphasized. As Lily Alfonso noted in her interview with Krumova (2014), "if the locals and government do not see the need for a fashion programme, how could we convince the world of our abilities?"

Though extremely critical, the government's participation goes beyond the establishment of a fashion institute, and would generally include articulated policies and deployed initiatives specifically aimed at developing the local fashion industry across its value chain. The Nigerian government has demonstrated a positive body language in this regard through efforts such as the Cotton Textile and Garment (CTG) policy which was part of the 2014 National Industry Revolution Plan, and the 100 billion naira Textile and Garment Intervention Fund. In addition, the government, through the Bank of Industry, endowed a two billion naira Fashion Fund. However, though these are laudable efforts, the implementation of the majority of these initiatives have been weak and ineffective. More political power needs to be demonstrated by the government to support the local fashion industry. In this area, there are also lessons to be learnt from both the established fashion capitals of the world, and the emerging global fashion centres. National and municipal authorities in Belgium worked collaboratively with key industry stakeholders in redefining the identity and branding of Antwerp around fashion (Godart, 2012). The Belgian government, till today, continues to support fashion events and festivals in the city. In Paris, during the 1980s and 1990s, the government enacted several public policies (including favourable tax regimes for businesses in the local fashion industry) and followed through on their implementation to ensure that the city maintained its primus inter pares status in the global fashion scene. These initiatives were championed by Jack Lang, the former Minister of Culture to the then French president, Francois Mitterrand (Godart, 2012).

These afore-mentioned examples show that government support does not have to be limited to financial grants, as seems to be the case in Nigeria. Political will can be demonstrated, for instance, in proactive measures taken to protect the intellectual properties of fashion designers. The absence of formal structures to protect designers from being ripped off their design collections, and the fact that there is also no social pressure to ameliorate the "copy-catting" of designs, make it difficult for established and emerging designers to thrive. It also makes it difficult to attract talented designers from other markets who are interested in exploring ways of incorporating the Nigerian fashion culture into their creations.

The Nigerian government can also intervene in improving the infrastructures that support the local fashion sector, such as the textile sector. This is an important lesson that can be learned from the case of Sao Paulo that is rapidly gaining momentum as an influential fashion centre because of the quality and sophistication of its primary sub-sectors (textile mills, fabric, yarn and thread production industries). It is sad to note that Nigeria once had a thriving textile industry that in its golden era (1985 to 1991) grew at an annual compounded rate of $67 \%$ and employed well over 2 million people who accounted for $25 \%$ of the country's manufacturing workforce at the time (Aibueku, 2016). Today only 25 of the 180 textile mills are still in operation, and even these function at less than $40 \%$ of their capacity (Aibueku, 2016). Most of the interventions of the government have been focused on banning importation of fabric in order to revive the local textile industry. But in this age of globalization, this is a failed strategy. Rather the government should focus on initiatives around stable electricity supply, mobilization of private sector investments, skills and capacity building, and deployment of newer technologies. The impact of the textile sector on African fashion culture (and specifically on the Nigerian fashion industry) is too huge to ignore. Today, 2.1 billion yards of African prints are sold annually, accounting for over $\$ 4$ billion in retail revenue (Aibueku, 2016). Unfortunately, these opportunities are being taken advantage of by non-Africans. As reported by Aibueku (2016), "China and India account for $60 \%$ and $21 \%$ respectively of African print fabric production. On the consumption side, West Africa accounts for $65 \%$ of the market with Nigeria accounting for $38 \%$ of the total demand for African print fabric".

Distribution is another key area where the local fashion industry can learn valuable lessons from other fashion centres around the world. In Europe for example, buyers and retailers like H\&M and Zara are key within the entire distribution process. In fact these influential fashion capitals operate a buyer-driven value chain, where value consumption in the fashion industry is predominantly facilitated by the retailers. 
The retailing segment of the fashion industry largely follow two models. The first model is where the designers themselves set up retail outlets (either solely or in partnership with other established retailers) to showcase and exclusively sell their design collections. The other model is where independent entrepreneurs set up distribution networks dedicated to retailing selected designers and their design collections. Either way, the buyers and retailers constitute an important part of the value chain because they make it easy for consumers to access these design collections.

The retail segment of the fashion industry is so advanced in developed fashion capitals to the extent that you usually have sections of the city (typically called "High Streets") dedicated to retailing luxury designer fashion items. Examples include Via Montenapoleone, Corso Venezia and Corso di Porta Ticinese (all in Milan); King's Road, Oxford Street, Regent Street and Jermyn Street (all in London); 34th Street in New York; and Rue de Rivoli in Paris. Designated and well-known fashion high streets are not common in Lagos, even though some have argued that Awolowo Street (in Ikoyi), Allen Avenue and Opebi (both in Ikeja) can pass for high streets. However, there are few luxury outlets in Lagos like Temple Muse and Leila Fowler that retail collections by Nigerian designers, and others owned by designers like Deola Sagoe and Tiffany Amber. A few foreign brands and fashion retail businesses (like Mango, Diesel) have established a presence in Lagos. In other cities like Abuja, Port Harcourt and Kaduna, there are also a number of local designer-owned outlets. However, this largely remains an untapped territory for individuals and businesses looking to key into the local fashion industry. This opportunity can also be of benefit to multinational retailing giants who are looking to connect the Western world with Nigerian fashion.

Even though there are quite a number of areas where the local fashion industry (represented by the city of Lagos) can learn valuable lessons from the global fashion capitals, there are also areas where the local industry have done relatively well. In terms of promotion, the industry stakeholders have successfully executed a growing number of impactful initiatives. For instance, today, the Lagos Fashion Week is one of the most prestigious fashion events in Africa, and is well attended by members of the international community. It attracts the top African designers, and has produced numerous emerging designers as well. Additionally, the Lagos fashion media is very active. Fashion bloggers, journalists, magazines, TV stations, books, modelling agencies and advertising outfits are connecting the industry with the rest of the world.

There is no doubt that the Nigerian fashion industry is vibrant and colourful, and has positioned the country as the next big thing in the global culture and creative industries. With a youthful and resourceful demographics and a leadership position in the African fashion scene, Nigeria is definitely too huge to ignore. Nevertheless, as has been noted, the fragmented nature of the local industry and other structural issues are threatening its global position. Recommendations on how these can be addressed have been suggested in the form of lessons from other global fashion centers. Implementing these recommendations will definitely result in deriving more benefits from the potentials of the local fashion industry. As Lloyd (2014) observed, "the successes of [Nigeria's] film and music sectors present a strong case for taking its fashion sector seriously and developing a strategy for doing so. If the institutional weaknesses in the industry are corrected then fashion can contribute to economic growth and position Nigeria as a major player in the international fashion market, in the way it has the potential to".

\section{Nigeria's music industry}

With over 350 ethnic groups and a rich multicultural tapestry, Nigeria is a country with deep roots in music. Broadly, three categories of music based on language and choice of instrument define the Nigerian music space (Letts, 2003). According to Letts (2003), there is the traditional music which is heavily reliant on local instruments and the dialect of the local people, and of which there are two variants: the classical variant usually accompanying some folklore, and the popular variant which have a commercial orientation and are performed for profit during events. The second category is the traditional-contemporary popular music, which are traditional music sung in local languages, but heavily influenced by western instruments. Finally, there is the contemporary Nigerian music which are very similar to western urban music in terms of genres, instruments, themes and production methods. Language used are usually native (Yoruba, Igbo, etc.), English and Pidgin English. Some contemporary Nigerian music artistes include WizKid, D’Banj, Flavour, Yemi Alade and Sinach.

Over the last two decades, Nigerian music has exploded onto the global scene. The demand for Nigeria's energetic and vibrant music content has risen dramatically both locally and internationally. The shift in the preference towards Nigerian content has seen the consumption of local media exceed the demand for foreign produced musical entertainments by a ratio of 80:20 (Storm Records, 2013). Many social events in Nigeria and the diaspora lean heavily towards Nigerian music to entertain guests. In addition, Nigerian music is fast becoming dominant on radio and television in 35 countries (currently, over $80 \%$ of music played on Nigerian local radio stations are Nigerian songs). On YouTube, there are already over 2 billion views of Nigerian music in the last 15 months alone (JRC Technical Report, 2016). Foreign interest is on the increase with a few offshore players seriously evaluating how best to tap into the opportunities provided by the Nigerian 
music scene. Spinlet (a Finish digital music distribution service) has already set up offices in Lagos to explore the growing local music space. The company, whose foray into the African market is funded by Verod Capital Management Limited, is signing distribution agreements with Nigerian music artistes, and making their songs available to a global audience. We are also witnessing more cross-border collaborations between Western and Nigerian artistes. As an example, the US-based record label "G.O.O.D. Music" has signed up a few Nigerian artistes and have entered partnership agreements with home-based labels like E.M.E. Records.

Perhaps the best example to illustrate how globalized and appealing Nigerian musical content has become is the Fela On Broadway musical tour which was based on the life and music of Fela Anikulapo Kuti, the father of Afrobeat. The show was a spectacular and inspiring success that starred Sahr Ngaujah and Kevin Mambo as Fela. It received 11 Tony Nominations and won 3 Tony Awards, grossed more than $\$ 40$ million in revenue and earned a million dollars in its opening weekend (the highest at the time). Tickets were sold for $\$ 75$, and in its over 34 previews and 465 performances, it was consistently sold-out and over-capacity. Fela On Broadway gives an indication of the inherent potential within the Nigerian music space, but it also represents the missed opportunities for the local industry. As popular and as successful as it was, no Nigerian was involved in the production.

Despite its massive appeal and wide acceptance, the Nigerian music industry is still faced with structural challenges. Without doubt, the taste of the typical Nigerian music has developed over time, production value of audio and visuals have improved, and the sound continues to evolve to reflect the sophistication of the consumers as well as the cultural richness and dynamism of the country's African roots, and the ever-changing social consciousness of the average Nigerian. But these mask the serious issues plaguing the industry and threatening the sustained global appeal and relevance of Nigerian music. These issues are not lost on industry stakeholders, many of whom have voiced their opinions with varying degrees of frustration. As noted by ID Cabasa (a recognized music producer of popular tracks) in an interview, "I don't think we have an industry, for you to have an industry, the industry must be defined, and you must have a structure... a [rallying] point where stakeholders will come together, and there's nothing like that, there is no functional process for an artist..." (Adedeji, 2016). Efe Omorogbe (a respected artiste manager) also said in an interview (Adedeji, 2016):

"What we have now is a lot of artists with indie [independent] labels run by their cousins, and their mothers, and their girlfriends, and their brothers and their grandmothers and all of that. And the entire business plan is in somebody's laptop, he carries it in his bag and hop to his car, and that is the entire business office, no overheads, no staff, no training, no experience, no expertise..."

Other individuals have expressed the same sentiments, pointing to factors such as mediocrity and unprofessionalism strangling the local music space. These statements by ID Cabasa and Efe Omorogbe summarize the unfortunate state of affairs that new generation artistes met in the early nineties (after the exit of major global record labels) when they started shaping the contemporary sound of Nigerian music (Adedeji, 2016). This situation largely subsists today. But before now, Nigeria had a well-structured music industry with global music organizations like Polygram, Decca, EMI and CBS (later Sony Music) developing and nurturing talents who learned and understood the structure of music, and practiced their craft with pride and a very high level of professionalism. The industry at the time generated a lot of interest from both local and international communities, and received support primarily from people like Haruna Ishola and Chief Tabansi who established Phonodisk and Tabansi Records respectively (Adedeji, 2016). As Adedeji (2016) pointed out, this was the "music industry that produced artists like Fela, Sonny Okosun and Onyeka Onwenu (EMI), IK Dairo and Ebenezer Obey (Decca), Sir Shina Peters, Adewale Ayuba, and Majek Fashek (CBS Records), Ras Kimono, Blackky, Oritz Williki, Evi Enda, Mandators, and Femi Kuti (Polygram Records)". But alas, the challenges of profitably distributing music in Nigeria became an insurmountable problem, and by 1989, the last of the global labels operating in Nigeria turned its back on the country. Shortly afterwards, the beautiful edifice of the Nigerian music industry came crumbling down (Servant, 2003 cited in Adedeji, 2016).

The distribution challenges of the Nigerian music industry has continued from the early nineties, and they appear to have escalated with the introduction of digital technology in the music business. Starting from the era of CDs and DVDs, to the miniaturization and subsequent portability of storage devices, and the emergence of light but high quality music formats (like the MP3), ease of reproduction and circulation of music content meant that artistes and producers of music relying on traditional business models suffered significant revenue losses. In fact, a significant majority of recorded music sold in Nigeria in the early nineties were through illegally produced tapes and discs (US Department of State Report, 1994). This unfortunate turn of events further destroyed what was left of the Nigerian music industry. In its history, the Nigerian music industry has moved from grace to grass, from its glorious old days to a modern reality that has no resemblance to its stellar past. But what is quite intriguing is how an industry that is largely structurally incapacitated is still able to produce content that enjoys global appeal. Nigeria's music industry is truly a curious case. 
As has been previously stated, even though Nigerian music is widely appreciated in the global space, the industry is still buffeted by numerous challenges. To achieve its full potential and ensure its future relevance, the industry must take concrete steps to mature in its status as an industry by global standards, and this necessarily involves addressing those key challenges and strategic issues identified below.

\section{Financing mechanisms-}

In the Nigerian music industry today, finding the right funding formula is still a big challenge. Financing remains informal and fragmented across the entire value chain of the local music business, making it very difficult to have sufficient capable and serious players in the production, packaging and distribution segments of the industry. In view of the potentials of the sector, one could have imagined that the dire financing situation will represent appealing opportunities for private sector financiers looking to develop the industry and enjoy significant returns on their investments, as was the case with Haruna Ishola and Chief Tabansi during the golden era of the Nigerian music industry (Adedeji, 2016). But that is not the case, because the structures that would allow these returns on investments are not in place, thus leading to some sort of vicious cycle. For instance, difficulties in assessing the credit-worthiness, viability and profitability of music projects have made banks and other financial institutions reluctant to invest. Lack of access to quality financing is one of the factors contributing to the mediocrity and unprofessionalism in the local music industry today. In more developed music industries, various sources of funding are available, including bank financing, venture capital investments, co-production agreements, sale of rights, state financing initiatives, equity financing, content distributors' financing, yield adjusted debt financing, government funding schemes, corporate sponsorships and merchandising and institutional financing. In Nigeria, self-funding appears to be the only readily available financing option. There are a few corporate sponsorships (especially with the FMCG companies and Telcos Nigerian Breweries, Guinness, MTN, Airtel, Etisalat and Glo) and government funding schemes, but the difficulty in securing such funds has made them impractical. The availability of largely informal financing mechanisms "significantly hampers the growth of the industry and discourages producers from innovating and pushing boundaries in terms of quality" (Chowdhury et al, 2008).

\section{Development of technical skills-}

The local industry is currently lacking a structured and formal way of developing talents and the skills needed at every point within the industry value chain - artistes, producers, sound engineers, visual effect artists, voice technicians, etc. The resultant effect is the gross shortage of competent individuals and the relatively poor quality of music productions (in terms of content, structure and engineering) compared to other more developed regions. This is the reason why Nigerian artistes looking to play on the global stage usually seek the services of music practitioners in other markets like the US, UK, South Africa, and now Spain.

Ofcourse, this is not to say that there is absolutely no form of training. There are several workshops and events organized by local players, and in some cases in partnership with a few small-sized training outfits in other regions. But these are largely informal and unstructured, and the content are not properly developed enough to provide the knowledge of the intricacies of the music business needed to adequately compete globally.

\section{Violation of intellectual property rights-}

Piracy and rights infringement is the resultant effect of a poor distribution system in the Nigerian music industry, which costs an estimated 50\% of potential revenue annually (Copyright Society of Nigeria, 2012). The first signs of piracy materialized in Nigeria in the 1970s when the introduction of cassette technology meant that the increasing local demand for Nigerian music could be somewhat met through illegal reproduction of successful albums which were at the time only released on vinyl. Global recording companies like EMI, Polygram, etc., made money by distributing music on vinyl, but the increasing availability of pirated cassette tapes deeply affected record sales. In fact, the pirates became so advanced (obviously driven by the economic benefits of their illegal activities), that many times, successful tracks became widely available on cassette tapes even before the vinyl record was official released (Adedeji, 2016). This phenomenon continued for over a decade, eventually forcing the global record companies to exit the Nigerian market.

As Adedeji (2016) noted, this exit created a distribution vacuum, which began to be filled by individuals who, aided by the introduction of CD and DVD technology as well as the excitement of different models of Chinese electronics and stereo sets flooding the market, started positioning themselves as conduits through which music reached the end consumers. In fact, they quickly became the de facto distribution channel, and organized themselves into a strong network. This network was largely based in Alaba International Market in Lagos, because incidentally, this was also the base of traders who dealt in electronics and computer parts, and thus who immediately saw the need and had access to resources to begin illegal mass reproduction of music on 
CDs and DVDs. Supported by the entrepreneurial spirit of the average Alaba trader, a pirate ecosystem was born, which till today exercises significant influence on the Nigerian music industry.

However, not everyone agrees that the music pirates (locally called Alaba Boys) are a menace. Some see them as a key part of the Nigerian music industry who form and nurture a mutually beneficial relationship with artistes. As Tade \& Akinleye (2012) noted, these pirates are seen as music promoters or markets who help upcoming Nigerian music artistes become well known and popular in a saturated music space, and in turn earn some revenue for their efforts. Upcoming artistes are typically supportive of this view, but immediately they become successful, they look at the pirates as pests who parasitically benefit from the fruits of someone else's hard work. What is usually lacking from this perspective (i.e. of considering pirate networks as beneficial) is the fact that artistes are not the only players hurt by the piracy business. There are other important stakeholders in the music industry value chain (e.g. sound engineers, producers, etc.) who cannot afford to sustainably run a music business and make a decent living because of the challenges brought about by piracy. And if these players are unsuccessful, there is no way the entire industry will be successful.

Piracy and copyright infringement took a different dimension with the advancement of digital technologies and the emergence of social media. Today, people can share and download music online, via their mobile devices or through portable music and storage devices (flash drives, iPods, etc.) and enjoy them both in private and public spaces, even earn some revenue off them, all without spending a dollar. This phenomenon is so prevalent in Nigeria, and some corporate organizations are just as guilty as individual. To illustrate this point, in June 2016, the "Copyright Society of Nigeria (COSON)... filed a 16 billion Naira law suit against MTN for music copyright infringement", after issuing several warnings on the unethical practices of the telecommunication company in terms of music usage (TechCabal, 2016). COSON has similarly filed an 11 billion Naira law suit against Etisalat, another telecommunication company operating in Nigeria.

\section{Inadequate distribution channels-}

With the industry rapidly moving towards digitization of content, the local music industry will continue to remain vulnerable to piracy due to inadequacy of formal distribution channels for both the local and international markets. A lot of Nigerian music is played in Europe and other continents, but the artistes and producers are not sufficiently compensated for their work because the channels through which these works are distributed are not properly set up to benefit the creators of music.

\section{Inadequate production facilities-}

Content producers lack the necessary equipment and facilities required to produce high quality content that is comparable to what obtains in more sophisticated markets. For example, it is difficult to point out a local music production facility similar to Abbey Road Studios in the UK. This challenge is not peculiar to the local music industry alone, but common to many sectors of the Nigerian culture and creative industries. Production facilities are an important part of the infrastructure of the creative industry, and without them, developments in the industry will always be limited.

As has been mentioned earlier, sometimes it is surprising to imagine how the Nigerian music scene has generated so much global interest with all the structural challenges facing it. Some have attributed this to the international success of home-grown musical legends like Fela Anikulapo Kuti (Letts, 2003). Others have pointed to the entrepreneurial and dogged spirit of the typical Nigerian artiste as a plausible explanation for this widespread appeal. But for the local music industry to get to the next level and firmly establish itself in the global culture and creative industries, a lot more still needs to be done. Taking a cue from how other music industries have developed, it is clear that the government needs to demonstrate more political will power and play a more active role in advancing the local music industry. Granted, the government has shown genuine interest in the industry. Its involvement, even though largely limited to financing, has been demonstrated via some notable initiatives aimed at formalizing the music sector and the wider entertainment industry. Examples include the establishment of the $\$ 200$ million Special Entertainment Fund planned to be disbursed by the Bank of Industry and the Nigerian Export Import Bank as single-digit interest rate loans; the planned construction of the $\$ 5$ billion film village in Badagry Lagos, which will include facilities designed to cater for the music sector; and the GEMS Entertainment Initiative, a project of the Ministry of Trade and Investment, supported by the World Bank and UK Department of International Development, aimed at formalizing the distribution models, improving access to finance and facilitating new business partnerships. However, between changes in government and bureaucratic inefficiencies, many of these initiatives have not made much impact on either the local music sector or the Nigerian culture and creative industries as a whole. Therefore the government needs to actually get more serious and use its existing organs to design, formulate and effectively implement practical policies. The role of the government cannot be over-emphasized because its activities will form the foundation for the sustainable involvement of the private sector. Private investors cannot significantly invest in the critical infrastructures of the music business if returns on their investments cannot be reasonably assured. For this to 
happen, the yawning gap in the revenue collection process has to be plugged, and this starts with an updated copyright and anti-piracy act that is relevant and dynamic to suit the ever-changing realities in the music business.

\section{Better enforcement of an updated copyright act-}

Musical works (songs, performances, event, etc.) fall under one of the categories protected by the Nigerian Copyright Act ("the Act"), which bestows upon the creator of the works certain rights that include "reproduction, publication, performance, adaptation and translation of the work" (Oyewunmi, 2011). The Act also exclusively confers the right to use, modify, distribute or profit from such works in any form whatsoever on the creator, who can extended the rights to others if he so chooses. This necessarily grants a criminal offense status to any action, deliberate or otherwise, that infringes upon these rights, and this offence is punishable by law. These specific provisions of the Act were designed to protect creators against piracy.

As the introduction of CDs and DVDs in the 1990s made piracy more rampant, the government responded with the establishment of the Copyright (Security Devices) Regulation in 1999, which was followed by the Copyright (Optical Discs Plants) Regulation, as advances in digital technology rendered the previous regulation ineffective. The Nigerian Copyright Commission (NCC) also followed up the amendments to the regulations with some public awareness campaigns, most notably the Strategic Action Against Piracy (STRAP) which encouraged citizens to join the fight against pirate networks. As piracy grew in sophistication, enabled by technology, the NCC again responded with the Copyright (Amendment) Bill in 2009 and shortly afterwards, the Cyber Security and Data Protection Agency Bill (Oyewunmi, 2011). The latter specifically focused on the Internet and aimed to protect individuals and businesses who used the Internet to also conduct their affairs. However, the bill did not sufficiently address the challenges and concerns against piracy that creators faced online. Not only were the necessary amendments required not made, the Act has not been updated since then to reflect current realities, especially in this age of social media and proliferation of portable and mobile devices.

In addition to updating the Act, the government (through appropriate organs) has to devise more effective means of enforcing the provisions in the act, but more importantly need to be totally and proactively committed to this process.

\section{Mobilizing access to finance-}

Private sector funds are more likely to make an impact in the music industry because they are usually accompanied by diligent management and technical expertise. Therefore, in addition to addressing the challenges related to piracy and copyright infringement, the government can formulate policies aimed at providing attractive private financing opportunities to the industry. India is a good example of where this has been successful. In 2001, the Indian government conferred an "industry" status on the local creative industry as part of a bold policy initiative. This made it possible for the entire industry to gain access to bank credit and institutional funding for new projects. In addition, the government implemented a revised tax regime that resulted in significant investments in the industry infrastructure. India also signed several international coproduction treaties with France, Brazil, Italy, Germany and the UK, all expected to facilitate collaboration between industry practitioners in India and these countries.

\section{Focus on skill development-}

With the support of the government, industry practitioners and private investors can work together to establish formal skill development institutes similar to the prestigious Berklee College of Music in Boston Massachusetts, one of the largest and most innovative contemporary music colleges in the world. This will drive more innovation and professionalism, and ultimately result in high quality creative output that can meet global standards. Skill development also includes policy makers and enforcement agencies who need to be abreast of changes in the industry in order to proactively formulate and deploy intervening measures to ensure a healthy development of the music business. In addition, there needs to be more interface between industry practitioners, the government (and its agencies) and the academia, because apart from facilitating knowledge transfer, academic researchers can contribute to projecting the voice of the local music industry onto the global scene, ultimately helping to firmly establish the industry's position in the global culture and creative industries.

\section{Establishing proper distribution networks-}

Distribution channels are the blood vessels of the music industry, and there should be proper government policies and regulation to guide the activities of all the stakeholders involved in music distribution, regardless of the format (online, offline, album tracks, performances, etc.). Importantly, these policies and regulation should address the lingering issue of royalty collection, as this is critical in sustaining the economy of the local music industry. These guidelines should also cover local, regional and international distributions, and if 
effectively implemented will reduce the need for piracy, as well as incentivize the private sector to actively participate in the development of the industry.

\section{Stakeholder collaboration-}

Presently, there are several music associations and trade unions in the music industry - Performing Musicians Association of Nigerian (PMAN), Music Label Owners \& Recording Industries Association of Nigeria (MORAN), DJs Association of Nigeria, Fuji Musicians Association of Nigeria (FMAN), just to name a few. Often, there is strife and discord within and amongst the associations, resulting in very limited collaborations both with themselves and with other key actors associated with the music industry no matter how marginally. Good collaborations among all these stakeholders could lead to positive developments like the development of artists, a united fight against piracy, improved industry ethics, establishment of support structures, consolidation of award ceremonies that will lead to the emergence of prestigious events similar to the Grammy Awards, etc.

\section{Industry branding-}

Efforts to develop and globalize the brand of the Nigerian music industry is a very key strategy in any plan to establish the local industry in the global culture and creative industries. The government is critical to this, and can support such efforts with several initiatives including participating in the organization of yearly local and international festivals that will showcase Nigerian talents. Such festivals will, over time, draw large audiences that can also be leveraged for economic benefits.

Despite the numerous challenges facing the local music industry, Nigerian music has been one of the country's most successful global exports. The dynamic and colourful spirit, steeped in traditional music practices and culture, is what has attracted people all over the world and endeared them to Nigerian music. It is not uncommon to hear Nigeria being described as "the musical heartbeat of Africa" and the "stronghold for African popular music" (Servant, 2003 cited in Adedeji, 2016) primarily because of the voluminous and creative musical output of a very active local music industry.

\section{CONCLUSION}

Globalization of the culture and creative industries is inevitable, and this phenomenon will continue to evolve at a rapid pace as communication technologies advance, and as more countries derive economic benefits from the culture and creative industries. This will also be facilitated as more international trade treaties are signed by more nation-states. Nigeria's position in the global culture and creative industries makes it possible to enjoy accruing benefits, both economic and otherwise. Today, the local film industry is the third largest in the world. The Nigerian fashion culture is making a global statement and influencing design creations in the Global North (Europe and North America). Nigerian music is listened to worldwide and still continues to attract global attention. Undoubtedly, Nigeria's position in the global space is quite prominent, as the assessment conducted in this paper has shown. However, this paper has also highlighted the fact that there are structural challenges threatening the country's current positioning and future relevance in the global space. Some of these include knowledge building and transfer issues, distribution bottlenecks, production concerns, etc. There is therefore an urgent need to address these challenges with practical and implementable interventions, some of which have been recommended in this paper. If these recommendations are effectively executed, they will go a long way in further strengthening Nigeria's position in the global space.

\section{ACKNOWLEDGEMENTS}

Special thanks to Dr. Obiaya with whom my numerous discussions (both within and outside the classroom) led to the development of this paper. His insightful contributions are hereby sincerely acknowledged.

\section{REFERENCES}

[1] Adedeji, W. (2016). The Nigerian music industry: Challenges, prospects and possibilities. International Journal of Recent Research in Social Sciences and Humanities , 3 (1), 261-271.

[2] Agunbiade, T. (2016, June 23). TechCabal. Retrieved June 27, 2016, from TechCabal: http://techcabal.com/2016/06/23/mtn-is-being-sued-for-n16bn-by-the-copyright-society-of-nigeria/

[3] Aibueku, U. (2016, February 16). In textile industry, a hidden goldmine. Retrieved June 20, 2016, from The Guardian: www.guardian.ng/features/youthspeak/in-textile-industry-a-hidden-goldmine

[4] Aspers, P., \& Godart, F. (2013). Sociology of fashion: Order and change. Annual Review of Sociology , $39,92-171$. 
[5] Bair, J., \& Gereffi, G. (2001). Local clusters in global chains: The causes and consequences of export dynamism in Torreon's blue jean industry. World Development , 29 (11), 903-921.

[6] Barkey, K., \& Godart, F. (2013). Empires, federated arrangements and kingdoms: Using political models of governance to understand firms' creative performance. Organization Studies , 34 (1), 79-104.

[7] Bhardwaj, V. (2010). Fast fashion: Responses to changes in the fashion industry. The International Review of Retail Distribution and Consumer Research , 20 (1), 165-173.

[8] Bonetti, E., \& Schiavone, F. (2014). Identifying and mapping strategic groups in the fashion industry. International Studies of Management \& Organization , 44 (1), 55-69.

[9] Breward, C. (2003). Fashion. Oxford: Oxford University Press.

[10] British Fashion Council. (2015, March). High-end and designer manufacturing. Retrieved June 20, 2016, from Manufacturing Report: http://www.thecreativeindustries.co.uk/media/292099/manufacturingreport.pdf

[11] Castells, M. (2000). The Information Age: Economy, Society and Culture - The Rise of the Network Society (Vol. I). Cambridge, MA: Blackwell.

[12] Chowdhury, M., Landesz, T., Santini, M., Tejada, L., \& Visconti, G. (2008). Nollywood: The Nigerian film industry. Harvard Business Review .

[13] Courault, B., \& Doeringer, P. B. (2008). From hierarchical districts to collaborative networks: The transformation of the French apparel industry. Socio-Economic Review , 6 (2), 82-104.

[14] Crane, D. (2000). Fashion and its social agendas: Class, gender and identity in clothing. Chicago: University of Chicago Press.

[15] Doeringer, P. B., \& Crean, S. (2006). Can fast fashion save the US apparel industry? Socio-Economic Review , 4 (3), 77-92.

[16] D'Ovidio, M. (2015). The field of fashion production in Milan: A theoretical discussion and an empirical investigation. City, Culture and Society .

[17] Ernst \& Young. (2015). Culture times: The first global map of cultural and creative industries. London: Ernst \& Young.

[18] Flew, T. (2002). Beyond ad hocery: Defining creative industries. Cultural Sites, Cultural Theory and Cultural Policy. Wellington, New Zealand: International Conference on Cultural Policy Research.

[19] Galloway, S., \& Dunlop, S. (2007). A critique of definitions of the cultural and creative industries in public policy. International Journal of Cultural Policy , 13 (1), 17-31.

[20] Godart, F. (2014). The power structure of the fashion industry: Fashion capitals, globalization and creativity. International Journal of Fashion Studies , 1 (1), 39-55.

[21] Godart, F., \& Mears, A. (2009). How do cultural producers make creative decisions? Lessons from the catwalk. Social Forces , 88 (2), 92-114.

[22] Hracs, B. (2012). A creative industry in transition: The rise of digitally driven independent music production . Growth and Change , 43 (3), 442-464.

[23] Hull, G., Hutchinson, T., \& Strasser, R. (2011). The music business and recording industry (Vol. III). New York: Routledge.

[24] Jennings, H. (2011). New African Fashion. Munchen: Prestel.

[25] Jones, S. (2002). Music that moves: Popular music, distribution and network technologies. Cultural Studies , 16 (2), 213-232.

[26] Krumova, K. (2014, May 14). The African fashion industry revolution. Retrieved June 12, 2016, from The Epoch Times: http://printarchive.epochtimes.com/a1/en/uk/nnn/2014/05-May/14/003_News.pdf

[27] Leurdijk, A., \& Nieuwenhuis, O. (2012). Statistical, ecosystems and competitiveness analysis of the media and content industries. Spain: Joint Research Centre.

[28] Lloyd, B. A. (2014, August 15). Nigeria's Flourishing Fashion Industry. Retrieved July 22, 2016, from Not Just A Label: https://www.notjustalabel.com/editorial/sleeping-giant-nigerias-flourishing-fashioindustry

[29] Makinde, D. O., Fajuyigbe, M. O., \& Ajiboye, O. (2015). Nigerian textile industry: A tool for actualising economic stability and national development. European Journal of Business and Social Sciences , 4 (8), 331-344.

[30] Martinez, J. G. (2007). Selling avant-garde: How Antwerp became a fashion capital (1990-2002). Urban Studies , 44 (12), 64-97.

[31] Nigerian Copyright Commission. (2009, May 3). The Optical Plant Regulation. Retrieved June 28, 2016, from Nigerian Copyright Commission: http://www.nigcopyright.org/Docs/OPTICAL_DISCS_REGULATIONS.pdf

[32] Oberhofer, M. A. (2012). Fashioning African Cities: The case of Johannesburg, Lagos and Douala. Street Notes , 20, 65-89. 
[33] Olawunmi, B. (2015, July 29). Increasing Profile of the Nigerina Fashion Industry. Retrieved July 22, 2016, from Newswatch Times: http://www.mynewswatchtimesng.com/increasing-profile-of-nigerianfashion-industry

[34] Oyewunmi, A. (2011). Towards sustainable development of Nigeria's entertainment industry in the digital age: Role of copyright law and administration. NIALS Journal of Intellectual Property , 74-102.

[35] Pinto, M. M., \& de Souza, Y. (2013). From garment to fashion production: An analysis of the evolution of the apparel industry in Brazil. Brazilian Administration Review , 10 (3), 304-322.

[36] PwC. (2014). Nigerian music market. South Africa: PricewaterhouseCoopers.

[37] Rantisi, N. M. (2002). The competitive foundations of localized learning and innovation: The case of women's garment production in New Yory City. Economic Geography , 78 (4), 441-462.

[38] Rocamora, A. (2009). Fashioning the City: Paris, Fashion and the Media. London: I.B. Tauris.

[39] Servant, J. C. (2003). 'Which Way Nigeria?' Music Under Threat: A Question of Money, Morality, SelfCensorship and Sharia. Copenhagen: Freemuse.

[40] Tade, O., \& Akinleye, B. (2012). 'We are promoters not pirates': A qualitative analysis of artistes and pirates on music piracy in Nigeria. International Journal of Cyber Criminology , 6 (2), 1014-1029.

[41] UNCTAD. (2010, March 2). Creative Economy. Retrieved June 28, 2016, from Creative Economy: http://unctad.org/en/docs/ditctab20103_en.pdf

[42] United States Congress. (2015, February 2015). The economic impact of the fashion industry. Retrieved June 20, 2016, from Joint Economic Committee: https://maloney.house.gov/sites/maloney.house.gov/files/documents/The\%20Economic\%20Impact\%20of $\% 20$ the \%20Fashion\%20Industry\%20--\%20JEC\%20report\%20FINAL.pdf

[43] White, N. (2000). Reconstructing Italian Fashion: America and the Development of the Italian Fashion Industry. New York: Berg.

[44] Wilstrom, P. (2012). A typology of music distribution models. International Journal of Music Business Research , 1 (1), 7-20.

[45] World Intellectual Property Organization. (n.d.). The African fashion design industry: Capturing value through intellectual property. Retrieved June 16, 2016, from WIPO: http://www.wipo.int/edocs/mdocs/mdocs/en/ompi_pi_dak_15/ompi_pi_dak_15_www_319536.pdf 